UDC: 005.95/.96:316.774

https://doi.org/10.18485/akademac_hrmo.2021.ch2

\title{
ZNAČAJ SELEKCIJE LJUDSKIH RESURSA ZA RAZVOJ MEDIJSKIH ORGANIZACIJA
}

Branislav Sančanin ${ }^{1}$

\begin{abstract}
Abstrakt: Privlačenje talenata i njihovo zapošljavanje u medijskim organizacijama u Srbiji, bez obzira na veličinu i vlasništvo, predstavlja kontinuirani proces koji obuhvata izbor kandidata koji ispunjavaju zahtevane uslove radnog mesta i njihovo dugoročno zadržavanje. Kada je fokus aktivnosti na izboru kandidata koji odgovaraju ili su najbliži traženim uslovima, govorimo o kompleksnom i odgovornom procesu selekcije, od koje se očekuje da opravda prognozu uspešnosti odabira kandidata. Pretpostavka uspešne selekcije su definisanje kriterijuma selekcije i specifikacija kandidata. Cilj rada je da se aktuelizuje ova tematika u svetlu globalizacije i turbulentnog tržišta rada i ukaže na značaj selekcije ljudskih resursa u medijskim organizacijama, kao ključnog procesa za ostvarivanje konkurentske prednosti i uspešnog poslovanja medijske organizacije. Pozitivan ishod procesa selekcije direktno je uslovljen privlačenjem dovoljnog broja kandidata sa odgovarajućim znanjima i sposobnostima u procesu regrutacije. Doprinos ovog rada ogleda se u sistematizovanoj vizuelizaciji aktivnosti procesa selekcije ljudskih resursa u medijskim organizacijama, kao i ostvarivanju konkurentske prednosti na medijskom tržištu na osnovu tzv. nevidljive aktive.
\end{abstract}

Ključne reči: ljudski resursi, selekcija, zapošljavanje, mediji, migracije

Fakultet za menadžment u Sremskim Karlovcima, Univerzitet "Union - Nikola Tesla" u Beogradu e-mail: branislav.sancanin@famns.edu.rs 


\section{UVOD}

Najviše zaposlenih u medijima u Srbiji u 2020. godini bilo je u proizvodnji televizijskog programa: 4.553 muškarca i 3.436 žena, što je neznatno više nego u 2019. godini, kada je ugovor o radu, odnosno ugovor o delu ili o obavljanju privremenih i povremenih poslova imalo 4.449 muškaraca i 3.334 žena. Broj zaposlenih na radiju je znatno manji: 133 muškaraca i 159 žena, što je, takođe, više nego godinu ranije (121:158). U štampanim medijima je zaposleno 1.322 muškaraca i 1.455 žena, i za razliku od elektronskih medija, zabeležen je manji broj zaposlenih nego 2019. godine (1.355:1.469). Pad broja zaposlenih u 2020. godini je i u novinskim agencijama, gde radi 147 muškaraca i 181 žena (156:182) (Krstić, 2021).

Glavne i odgovorne urednika medija u Srbiji uglavnom čine muškarci $62,30 \%$, dok su žene zastupljene u $37,70 \%$ slučajeva ${ }^{2}$ (APR, 2021)

Nasuprot pada broja zaposlenih, u Srbiji je vidljiv višegodišnji trend povećanja broja medija. Od ukupno registrovanih 2.508 , najviše je dnevnih i periodičnih novina - 937 i internet portala i samostalno uređivački oblikovanih stranica - 835 (APR, 2020). Broj medija nastao u prethodnom priodu je nesrazmeran komercijalnim i budžetskim prihodima, odnosno njihov broj značajno premašuje kapacitet tržišta na kome ostvaruju prihode.

Rad u medijima je sve manje privlačan, a među najvažnijim razlozima prepoznaju se nedefinisano radno vreme, slobodni dani i godišnji odmor, niske zarade, lako raskidivi ugovori o radu, a deo on-lajn medija je u tzv. sivoj zoni, pa je i položaj radno angažovanih nejasan. Sindikat novinara Srbije sproveo je 2018. godine istraživanje o radnim pravima i sindikalnom angažovanju novinara i medijskih radnika, a na bazi 100 ispitanika utvrđeno je da je prosečna zarada kod $70 \%$ ispitanika u digitalnim medijima na nivou minimalne, da ugovor na neodređeno vreme ima samo $40 \%$ zaposlenih, da više od polovine ističe da radi duže od osam sati dnevno i vikendom (SINOS, 2020). Novinarska, kao i ostale medijske profesije nisu prepoznate u zakonskoj regulativi u smislu propisivanja uslova za obavljanje brojnih specifičnih poslova. Posledično tome, poslodavci ne osećaju obavezu da zaposlenima omoguće obuke i treninge, čime bi se njihova efikasnost i produktivnost, prateći savremene trendove u profesiji, podigli na znatno viši nivo.

2 Predstavljeni podatak je presek stanja u elektronskim bazama Agencije za privredne registe na dan 30. septembar 2021. 


\section{Definisanje kriterijuma selekcije}

Proces selekcije se najčešće definiše kao izbor kandidata između više njih, koji najviše odgovaraju unapred postavljenim kriterijumima. To je zahtevan proces $u$ kome se teži kreiranju kohorti u kojima se selektuju kandidati prema njihovom znanju, sposobnostima i veštinama. Cilj je da se interes kandidata i medijske organizacije podudara, tako da su šanse kandidata za dobijanje ponude za posao u pozitivnoj korelaciji sa njihovih kompetencijama.

Kriterijumi selekcije se najčešće definišu u odnosu na specifikaciju kandidata (Lewis, 1985):

- Organizacioni kriterijum selekcije - sadrži sve karakteristike kandidata koje vrednuje organizacija;

- Funkcionalni kriterijum selekcije - definiše brojne i različite kriterijume adekvatnih interpersonalnih sposobnosti pojedinaca u organizacionoj jedinici zaduženoj za ljudske resurse;

- Individualni kriterijumi radnog mesta - koji se nalaze u opisu svakog radnog mesta, kao i u specifikaciji zahteva za odgovarajućim kandidatima sačinjenim na bazi analize posla.

Selekcija je proces u kome zainteresovane strane donose zasebne odluke, pri čemu medijska organizacija treba da odluči da li će ponuditi posao zainteresovanom kandidatu, a kandidat treba da odluči da li će prihvatiti ponudu (Čerović, Knežević, 2019).

Proces selekcije bi trebalo da opravda najbitniji parametar zapošljavanja prognozu uspešnosti odabranog kandidata, te se kao bazični standardi selekcije naglašavaju opravdanost i pouzdanost (Đorđević Boljanović i sar., 2020: 68). Pojednačno identifikovane razlike koje imaju uticaja na selekciju moguće je sagledavati kroz objektiv sposobnosti, osobina ličnosti i kompetencija (Čerović, 2013). Definiciju sposobnosti, koje mogu da budu intelektualne, perceptivne i psihomotorne, možemo svesti na to da je reč o karakteristikama koje kandidati poseduju, a što predstavlja uslov za ostvarivanje očekivanih rezultata na radnom mestu. Osobine ličnosti objedinjavaju sve ono što kandidata čini različitim od ostalih, a vidljive su kroz ambicioznost, kreativnost, optimizam i zabrinutost, a nekada i kroz agresivnost. Kompetencija označava sposobnost kandidata da uspešno obavlja zadatak ili posao.

Prvi korak u procesu selekcije kandidata je prikupljanje podataka: popunjen prijavni obrazac i preporuke, a od koristi je intervju koji sa kandidatima obavlja menadžer za ljudske resurse. Intervju je dvosmeran proces, koji nudi šansu za oce- 
nu sposobnosti i veština, kao i prethodnog iskustva kandidata, čineći to iz ugla potreba prema opisu radnog mesta. U slučaju kada intervju nije dovoljan, odnosno kada je neophodno načiniti i sledeći korak, primenjuje se testiranje kandidata izborom testova sposobnosti, ličnosti, postignuća, zatim testiranje sposobnosti za obuku, testiranje posebnih, zdravstvenih i fizičkih sposobnosti, a ponekad se upotrebljava i poligrafsko testiranje (Torrington et al., 2004:199). Sledi pisanje kratkog rezimea o kandidatima koji su ušli u uži izbor, provera njihovih referenci, donošenje odluke o zapošljavanju i obaveštenje kandidata o pozitivnom ishodu selekcije, kao i obaveštavanje o rezultatima selekcije svih koji nisu izabrani.

Slika 1. Proces selekcije kandidata

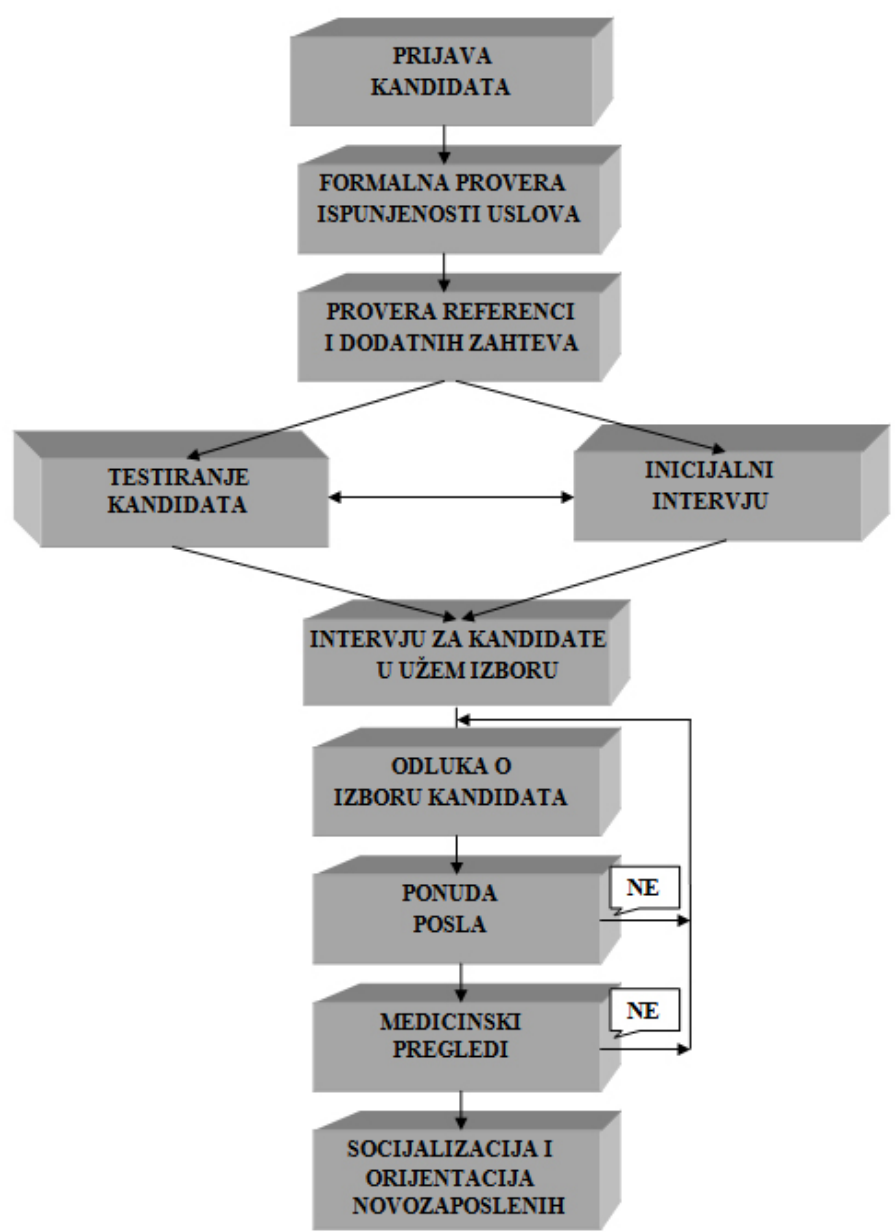

Izvor: autor, 2021. 
Mada proces selekcije integriše brojne različite iteracije, koje se prilagođavaju zahtevima posla, Štangl-Šušnjar i Zimanji (2006: 166) sugerišu model selekcije sa sledećim elementima: prijem molbi, testovi, intervju, preporuke i provera dokumentacije, ocena zdravstvene sposobnosti, razgovor sa rukovodiocem, prikaz posla i odluka o zapošljavanju.

Često se menadžerima za ljudske resurse poverava zadatak da ocene sertifikovane kandidate u nekoj oblasti rada, odnosno očekuje se da im daju prednost u odnosu na druge bez sertifikata. Dobrovoljna sertifikacija afirmativno govori o kandidatima sa sertifikatima, sobzirom na to da obim i priroda sertifikata u znatnoj meri olakšava i pomaže menadžerima zaduženim za proces zapošljavanja (Farashah et al., 2019).

Stvarnje pozitivne slike u javnosti o organizaciji kao poželjnom mestu za rad trebalo bi da se posmatra kao kontinuirani proces koji ima značaj i onda kada ishod zapošljavanja nije povoljan za pojedine kandidate, tj. u situaciji kada je neophodno da im se dostavi informacija o okončanju selekcije koja za njih nije povoljna. Insistira se na personalnom pristupu svakom kandidatu, pri čemu treba izbegavati slanja automatizovanih poruka u kojima, po pravilu, izostaju važne informacije o tome šta je bilo opredeljujuće u donošenju konačne odluke kojim kandidatima da se ponudi da potpišu ugovor o radu.

"Oceniti put do posla", naziv je projekta koji je u 2020. godini realizovala "Infostud grupa", gde je 14.766 kandidata ocenjivalo 44.908 oglasa kod 5.811 poslodavaca ${ }^{3}$. Čak $84 \%$ kandidata koji su podneli prijave na oglas za upražnjena radna mesta nije dobilo povratnu informaciju, tako da je upravo izostanak obaveštenja o ishodu najlošije ocenjena stavka. Taj podatak ozbiljno urušava imidž organizacija, na šta ukazuje podatak da je $68 \%$ anketiranih izjavilo da se ne bi ponovo prijavili na oglas kod istog poslodavca, dok više od $72 \%$ kandidata ne bi preporučilo bliskim osobama da se prijave na oglas kod tog poslodavca (www.hrlab.rs, 2020).

Zapošljavanje je moguće sagledati i kao kritičnu fazu upravljanja ljudskim resursima, ceneći da organizacija obezbeđuje šansu da stekne kompetencije koje su neophodne za obavljanje poslova (Vukonjanski i sar., 2012). Za kandidata iz organizacije, primenjuju se dodatne metode koje uključuju ocenu uspešnosti i ocenu saradnika.

Ipak, konačna odluka o prihvatanju posla pod ponuđenim uslovima je na kandidatu, uz zadovoljenje zdravstvene sposobnosti za određeni posao.

Nakon izbora kandidata, kroz proces socijalizacije, novozaposlene je potrebno upoznati sa organizacijom, organizacionom kulturom, kodeksom ponašanja,

3 U istraživanju su učestvovali kandidati koji su putem sajta https://poslovi.infostud.com/ dobili priliku da ocenama od 1 do 5 vrednuju način na koji su organizacije zakazivale intervju, kvalitet dobijenih informacija o radnom mestu, brzinu procesa selekcije i obaveštenje o konačnom ishodu. 
očekivanjima i sl. Organizacija uvodi u posao nove članove kolektiva kroz realizaciju odgovarajućih programa, koji prema autorima Budaković i Peštek (2018) sadrži dve grupe aktivnosti: orijentaciju i obučavanje za rad na poslovima.

Ukazujući na to da je mali broj empirijskih istraživanja koja utvrđuju konačne rezultate i navode konkretne varijable za determinaciju uspeha organizacione socijalizacije, Ratković-Njegovan i Vukadinović (2011:103) preciziraju da je reč o složenom fenomenu, koji zahteva interdisciplinarni pristup, s obzirom na to da delovanje međusobno povezanih subjekata u različitim tehnološkim, socijalnim, ekološkim, etičkim, kulturološkim i drugim uslovima jeste multifaktorsko.

Cilj organizacije je da minimizira rizik kod privlačenja i izbora nedovoljno kvalifikovanog osoblja na svim hijerarhijskim nivoima, a razlog su visoki troškovi i posledice promašaja i grešaka. Pored direktnih troškova, potrebno je ceniti i indirektne, kao što su troškovi oglašavanja, izgubljenog vremena tokom razgovora sa kandidatima, kao i troškovi za vreme socijalizacije novozaposlenih, a oni se procenjuju na dve do pet godišnjih zarada određenog radnika (Pržulj i sar., 2014: 42).

\section{Provera radnih biografija i preporuka}

Radna biografija predstavlja relevantan izvor informacija o kandidatu, a prilaže se uz prijavu na oglas. Danas su u upotrebi uglavnom standardizovani obrasci, što biografije čini lakše uporedivim sa zahtevanim uslovima za rad, kao i sa ostalim kandidatima. Ona bi trebalo da sadrži ime i prezime kandidata, punu adresu i kontakt telefon, mesto i godinu rođenja, vrstu i stepen stručne spreme, odnosno završene škole ili fakultet sa godinama završetka formalnog obrazovanja, profesionalno interesovanje, obuke i treninzi, radno iskustvo (vrsta i vreme provedeno na svim prethodnim radnim mestima) i lične osobine. Radna biografija pruža uvid u celokupno dotadašnje radno angažovanje, a naročito se uvažava napredovanje u karijeri i moguće praznine u radnom angažmanu, kao i eventualnu promenu zanimanja i profesionalna interesovanja.

Mada preduzeća za vreme procesa zapošljavanja teže da izaberu kandidate koji ispunjavaju zahtevane uslove, bitna je procena da li kandidat svoj profesionalni razvoj vidi u toj organizaciji. Uvažavajuči to da promene radnih mesta i preduzeća nije moguće izbeći, taj pokazatelj kod kandidata ne treba posmatrati kao diskvalifikujući. Naime, uvek postoji mogućnost da takvi zaposlenici u određenom vremenskom periodu prepoznaju sve vrednosti koje ranije nisu mogli da uoče i da donesu odluku o ostanku u preduzeću.

Relevantne informacije o kandidatima mogu se dobiti iz preporuka, kao potvrda prethodne uspešnosti. Preporukama se potvrđuju informacije navedene $u$ 
prijavi na oglas i radnoj biografiji, ali i vizuelizuje dotadašnji radni angažman u drugim organizacijama. Međutim, Jovanović Božinov i sar. (2008: 133) ističu da neka istraživanja ukazuju da je pouzdanost preporuka veoma niska, pre svega zbog izražene subjektivnosti, a podložne su i greškama, pa čak i zloupotrebama.

\section{Testiranje kandidata}

Testovi predstavljaju skupove zadataka, izabranih prema određenim principima, koji omogućavaju da se na objektivan način ispitaju određene osobine ili neki psihički procesi (Štangl Šušnjar, Zimanji, 2006: 164). U praktičnoj primeni su uobičajena dva koncepta testiranja: validnost i pouzdanost.

Da bi test bio validan mora da ispituje ono za šta je namenjen, a validnost mu se potvrđuje stavljanjem u odnos rezultata testiranja sa rezultatima koje ostvaruju izabrani zaposlenici. Bez obzira na odluku o tome koja vrsta testova će biti korišćena, medijske organizacije bi trebalo da dodatnu pažnju poklone odabiru testova, ceneći njihovu validnost (Marchington \& Wilkinson, 2002). Dva bazična dokazivanja validnosti testa su (Dessler, 2007: 114): test na osnovu kriterijuma i test na osnovu sadržaja. Potvrđivanje testa na osnovu kriterijuma znači da će oni kandidati koji pokažu dobre rezultate na testu, imati i dobre rezultate na poslu. Validnost testa na bazi sadržaja potvrđuje se tako što se obezbedi test koji na odgovarajući način odslikava sadržaj posla.

Pouzdanost se odnosi na koncept doslednog merenja, što u praksi znači da će se svaki put kada se upotrebljava određena metoda selekcije doći do istog rezultata. Relevantnost valjanosti se ogleda u tačnosti merenja i pruža nam tumačenje ocena koje su stečene određenim metodama selekcije, ali samo u odnosu na svrhu za koju se koristi test (Cooper et al., 2003: 49-53).

Pojedini autori izražavaju sumnju u preveliku upotrebu i poverenje u psihometrijske testove, naročito ukoliko se na osnovu rezultata predviđaju budući radni učinci (Bratton \& Gold, 2003).

Razvoj internetske komunikacije omogućio je manjim medijskim organizacijama da sprovode on-lajn selekciono testiranje, što ima snažno uporište kod zagovornika smanjenja troškova, čineći testiranje, bez vremenskih i prostornih ograničenja, pristupačnim za slabije plaćene poslove (Beadwell \& Wright, 2003). Glavni nedosttak upotrebe internetskog testiranja je nemogućnost kontrolisanja okruženja u realnom okruženju i vremenu, kao i u otežanoj proveri identiteta kandidata (Bratton \& Gold, 2003).

U okviru selekcije kandidata za posao primenjuju se brojni testovi, koji se mogu diferencirati na dve vrste (Jovanović Božinov i sar. 2008: 134): 
- Psihološki testovi: koriste se za procenu sposobnosti, znanja i veština, osobina ličnosti i interesovanja kandidata za posa, čime se ispunjavaju dva cilja: dobija se jasna slika o sposobnostima i kvalitetima kandidata i kreiraju kvalitetnije procene o njihovoj budućoj uspešnosti;

- Testovi vezani za posao: ovi testovi podrazumevaju testove uzorka posla, testove sposobnosti sticanja veština i probni rad.

\subsection{Psihološki testovi}

Najstariji i najučestaliji, ujedno i najsporniji alati za selekciju kandidata za posao su psihološki testovi (Roberts, 2005: 132).

Jovanović Božinov, Kulić i Cvetkovski (2008: 135) načinili su podelu psiholoških testova na osnovu nekoliko kriterijuma:

- Predmeta testiranja: testovi sposobnosti, testovi znanja i veština, testovi ličnosti i testovi interesovanja;

- Način postavljanja i rešavanja zadataka za vreme testiranja (verbalni i neverbalni testovi);

- Načina primene testova: individualni i grupni (individualni i grupni testovi).

Testovi sposobnosti se koriste kako bi se procenile primarne mentalne sposobnosti potencijalnih kandidata, (testovi verbalnog ili apstrktnog zaključivanja, numeričkih sposobnosti i sl.). Učestalost upotrebe ovih testova rezultat je njihovog doprinosa egzaktnosti i pravičnosti procesa selekcije. Autorke Štangl Šušnjar i Zimanji (2006: 167) ukazuju na to da testovi sposobnosti nude informacije o latentnim mogućnostima pojedinaca, odnosno predispozicijama za sticanje određenih veština i znanja.

Testovi znanja i veština treba da potvrde znanja, veštine i navike kandidata, s obzirom da su to preduslovi za obavljanje određenog posla.

Testovi ličnosti se koriste kada je potrebno ispitati osobine kandidata koje su važne za obavljanje poslova. Razlikuju se dve vrste testova ličnosti: objektivni testovi i projektovani testovi ličnosti. Kod objektivnih testova ličnosti (testovi prisilnog izbora) kandidatima se daje niz pitanja i tvrdnji iz svakodnevnog života, a od njih se očekuje da izaberu jedan od ponuđenih odgovora. Projektovani testovi ličnosti su koncipirani da kandidat sam treba da da interpretaciju ponuđenog sadržaja, a osobine ličnosti procenjuju se na osnovu odgovora. 
Čerović (2019: 136) ističe da se primena testova ličnosti u prognostičke, odnosno selekcione svrhe bazira na njihovoj prirodi koju karakteriše: ispitivanje kvalitativnih osobina ličnosti, kompleksnost i fluidnost osobina, rezultati koji se baziraju na iskazima, što je ponekad zbog neiskrenosti kandidata diskutabilno i izostanku pravih i pogrešnih odgovora.

Testovima interesovanja treba otkriti profesionalna intresovanja kandidata i njihovu kompatibilnost sa interesima zaposlenih koji uspešno obavljaju radne zadatke. Ovi testovi su zasnovani na pretpostavci da su ljudi uspešniji u poslu ukoliko rade posao koji vole.

\subsection{Testovi vezani za posao}

Najučestaliji testovi vezani za posao su testovi uzorka posla, testovi sposobnosti sticanja veština i probni rad.

Testovi uzorka posla zasnovani su na pretpostavci da je uspešnost u prethodnom periodu dobar pokazatelj radne uspešnosti u narednom vremenu. Provera je bazirana na odabranom uzorku standardizovanih radnih zadataka, tako da se od kandidata očekuje da obave konkretan i unapred definisan posao na osnovu čega će biti procenjeno njegovo umeće u odnosu na zahteve radnog mesta.

Testovi sposobnosti sticanja znanja služe za proveru sposobnosti kandidata da ponove pokazane radnje i aktivnosti, a uglavnom se preferiraju za proizvodne poslove.

Probni rad je jedan od najprimenjivanijih provera znanja, veština i sposobnosti kandidata potrebnih za obavljanje određenog posla, čime se dobija jasna procena o usklađenosti potencijala kandidata sa zahtevima posla. Pavlović (2016: 141) ističe da će poslodavac povećati šansu da zaposli poštenu osobu ukoliko kandidat uradi test integriteta kojim se procenjuje njegovo poštenje za posao koji će mu biti poveren. $\mathrm{U}$ tom smislu koriste se otvoreni test integriteta (direktno postavljanje pitanja o tome šta kandidat oseća ili misli o krađi ili sankcionisanju neetičkog ponašanja) i test zasnovan na ličnosti (procena poštenja kandidata na bazi psiholoških karakteristika, kao što su pouzdanost i savesnost).

S obzirom na to da rezultati na testu najčešće pokazuju samo $25 \%$ varijacija u merenju učinka, preporuka je da se testovi ne koriste kao jedina tehnika u procesu selekcije, već kao dopuna drugim tehnikama. Testovi uglavnom pokazuju one kandidate koji će biti neuspešni, nego što pokazuju one koji će ostvariti željeni uspeh na radnom mestu (Dessler, 2007: 116). 


\section{Intervju}

Intervju je ciljno usmeren razgovor s namerom da se ispitaju sposobnosti kandidata za obavljanje posla za koji je podneo prijavu (Buble, 2006: 392) i predstavlja dominantnu metodu selekcije prijavljenih kandidata (Roberts, 2005) s ciljem da se još u inicijalnoj fazi detektuju znanja, veštine, iskustvo i specifične osobine važne za obavljanje posla.

Milić (2011) naglašava da je intervju neizostavan u procesu selekcije, čak i kada se upotrebljavaju drugi metodi s obzirom da je to prilika da se prikupe neophodne informacije o kandidatu, ali i mogućnost koja se daje kandidatu da dobije potrebne informacije o organizaciji, kao i vreme kada je potrebno utvrditi sposobnost kandidata za uspešno obavljanje posla.

Kao najučestalije greške koje se javljaju tokom intervjua, Stojadinović i Marinković (2015: 76-77) navode:

- Prebrzo donošenje ocena, uglavnom zbog pridavanja prevelikog značaja prvom utisku o kandidatu;

- Nedovoljno poznavanje radnog mesta, što posledično onemogućava izbor najboljeg kandidata za to radno mesto;

- Prevelika usmerenost na negativne informacije;

- Greške uzrokovane redosledom kandidata dovode ispitivača u situaciju da ponekad daju bolje ocene prosečnom kandidatu nakon nekoliko lošijih kandidata;

- Tenzije da se zaposle radnici negativno utiče na ispitivače tako da daju bolje ocene kandidatima kada je kvota regrutovanja niža;

- Neverbalno ponašanje ima snažan uticaj na odluku ispitivača.

U odnosu na kriterijume, diferencirano je nekoliko vrsta intervjua koji se koriste prilikom selekcije kandidata:

- Vrsta intervjua prema obliku;

- Vrsta intervjua prema broju učesnika;

- Vrsta intervjua prema njihovoj ulozi u procesu selekcije.

\subsection{Vrsta intervjua prema obliku}

Intervju na osnovu oblika može da bude nestrukturisani, polustrukturisani i strukturisani. 
Karakteristika nestrukturisanog intervjua se ogleda kroz način postavljanja pitanja, gde ispitivač postavlja pitanja prema svom nahođenju (Dessler, 2007: 122). U suštini, ova vrsta intervjua ima visok stepen fleksibilnosti, što posledično generiše nekonzistentne podatke o kandidatu (Bogićević Milikić, 2006: 134; Noe et al., 2016: 186), odnosno rezultati nestrukturisanog intervjua nisu dosledni i teško ih je koristiti u međusobnoj komparaciji prijavljenih kandidata, pa je prosečan koeficijent valjanosti znatno ispod strukturisanog intervjua (Cook, 2004), a to u praksi može da predstavlja važan razlog za različitu procenu kandidata (Roberts: 2005).

Prilikom strukturisanog intervjua koristi se set standardnih pitanja, koja se postavljaju svim kandidatima s ciljem jednostavnijeg poređenja njihovih referenci (Jovanović Božinov i sar., 2008: 152), a u idealnom kontekstu pitanja su povezana sa zahtevima posla i integrišu znanja, veštine i iskustvo (Noe et al., 2016: 186). Kako se ista pitanja postavljaju svim kandidatima po unapred utvrđenom redosledu, značajno su smanjene moguće greške prilikom ocenjivanja.

Intervju koji unapred sadrži sva strukturisana pitanja, ali se dozvoljavaju i dodatna pitanja, naziva se polustrukturisani intervju.

\subsection{Vrsta intervjua prema broju učesnika}

Karakteristika individualnog intervjua je što se realizuje jedan-na-jedan, gde se nalaze osoba koja je zadužena za sprovođenje intervjua i kandidat, mada postoji i opcija organizovanja panel-intervjua, odnosno intervjua gde više ispitivača postavljaju naizmenično pitanja. Ceneći to da više osoba sluša iste odgovore, može se zaključiti da panel-intervju osigurava veću pouzdanost i efikasnost u odnosu na individualni intervju (Noe et al., 2016: 187).

Dosta sličnosti sa panel-intervjuom nalazimo u organizovanju timskog intervjua, gde osim osoba zaduženih za intervju, participiraju i buduće kolege, čime se povećava učešće zaposlenih u donošenju odluka, što bi u sledećem koraku, tokom procesa socijalizacije trebalo da pokaže pozitivne efekte.

\subsection{Vrsta intervjua prema njihovoj ulozi u procesu selekcije}

U odnosu na ulogu u procesu selekcije kandidata, razlikuju se inicijalni, dijagnostički i prijemni intervju.

Od inicijalnog intervjua se očekuje da već na startu izdvoji kandidate koji ne odgovaraju zahtevima navedenim u oglasu za popunu upražnjenog radnog mesta. Inicijalni ili preliminarni intervju, po pravilu, traje kratko, a odluku o eliminaciji 
iz daljeg procesa donosi osoba koja vodi intervju. Dijagnostički intervju podrazumeva detaljniji razgovor sa kandidatima, s ciljem dobijanja svih relevantnih podataka i informacija o kandidatu, kao i da bi se procenila njihova usklađenost sa potrebama koje proističu iz zahteva radnog mesta. U finalnoj fazi organizuje se prijemni intervju koji označava razgovor sa kandidatima koji su uspešno prošli sve prethodne faze. Za vreme razgovora kandidat dobija priliku da dobije sadržajnije informacije o radnom mestu, a to je istovremeno i dodatna prilika za organizaciju da dobije informacije o personalnim ambicijama i profesionalnim planovima svakog pojedinca.

Multinacionalno poslovno okruženje je dodatni izazov za menadžere koji bi trebalo da cene kulturne razlike, kako bi se prevenirali mogući problemi. To je razlog što se od obučenih i blagovremeno informisanih menadžera zaduženih za selekciju očekuje da procenjuju znanje, veštine i iskustvo, da harmonizuju i prilagode redosled i sadržaj pitanja, ali i da pruže jednake šanse svim kandidatima i garantuju zaštitu podataka o ličnosti.

Intervju je u procesu selekcije gotovo neizostavan, a to potkrepljuju sledeći pokazatelji: u Finskoj i Danskoj - 99\%, Portugaliji - 97\%, Francuskoj - 92\%. Velikoj Britaniji - 90\% i Nemačkoj 86\% (Cook, 2004).

Za vreme intervjua procenjuju se brojni različiti atributi kandidata, a najčešće ličnost - $35 \%$, socijalne veštine $-28 \%$, mentalne sposobnosti $-16 \%$, dok se najmanje vremena i pažnje posvećuje interesima i sklonostima kandidata - 4\% i pojedinačnoj prikladnosti organizaciji - 3\% (Huffcutt et al. 2001).

\section{Jednake mogućnosti zapošljavanja}

Podsticanje koncepta jednakih mogućnosti zapošljavanja trebalo bi da bude neizostavan segment javnih politika i praksi, kako bi napori na smanjenju diskriminacije imali željene rezultate. Jednak pristup poslovima ima dodatnu relevantnost kada se posmatra u kontekstu procesa globalizacije i"rata za talente", gde se naglašava pravo da svi imaju isti tretman prilikom sprovođenja procesa zapošljavanja. Stoilkovska, llieva i Gjakovski (2015: 283) preciziraju da se koncept jednakih mogućnosti prvobitno odnosio na uočenu diskriminaciju zasnovanu na rasi, religiji i polu, ali je kasnije prošireno na starost, trudnoću i osobe sa invaliditetom.

Strategija zapošljavanja u Republici Srbiji od 2021. do 2026. godine predviđa uspostavljanje stabilnog i održivog rasta zaposlenosti koji se zasniva na znanju i dostojanstvu rada. Na taj način, kroz strateški dokument konstituiše se unapređena međusektorska komunikacija i saradnja privrede, finansija, obrazovanja i socijalne zaštite, čiji bi rezultati trebalo da budu vidljivi kroz realizaciju politike zapošljavanja u gradovima i opštinama (Vlada Republike Srbije, 2021). 
Radi unapređenja položaja mladih, osoba sa invaliditetom, korisnika socijalne pomoći, kao i ostalih marginalizovanih grupa, predviđene su i posebne mere podrške, ceneći kontekst dinamičnosti, promenjivosti i konkurencije na tržištu rada. Primenu afirmativnih mera u procesu zapošljavanja neophodno je sagledavati u kontekstu unapred identifikovanih ugroženih grupa, kako bi se konkretnim merama osnažile njihove šanse kao objektivno teže zapošljivim kategorijama.

Složen i odgovoran zadatak selekcije, kao i u prethodnoj fazi regrutacije potencijalnih kandidata za radna mesta u medijskim organizacijama, sve češće obuhvata i one koji su ostvarili pravo na penziju po osnovu godina života, odnosno radnog staža. To je jedan od načina da se pomogne starijem stanovništvu, koje se suočava sa materijalnim problemima, a trend povratka penzionera na tržište rada biće izražen u onoj meri u kojoj penzije budu realno manje od zarada zaposlenih. Korist organizacija je u tome što se angžovanjem starijih osoba smanjuje nedostatak veština i iskustva između onih koji su ostvarili pravo na penziju i mladih koji su završili formalno obrazovanje. Nikitović (2019) ističe da se u Srbiji do 2030. godine očekuje zadržavanje trenda rasta starijih od 65 godina, kao i da bi tek sredinom ovog veka broj starijih bio približno današnjem. Na poslodavcima je zadatak i odgovornost da prepoznaju izazove i vrednosti zajedničkog rada starijih i mladih i da na bazi sinergije maksimiziraju korist od starosne raznolikosti u organizaciji (Smeaton \& Parry, 2018).

Prema nekim projekcijama, Velika Britanija će u narednih deset godina potraživati 13,5 miliona radnika, a u istom periodu škole i fakultete će završiti sedam miliona mladih (CIPD, 2012). Deficit radne snage vidljiv je i u zemljama Evropske unije, gde se u naredne tri decenije očekuje smanjenje radno sposobnog stanovništva između milion i milion i po godišnje, uz istovremeno povećanje broja starijih od 60 godina brzinom od dva miliona godišnje (Smeaton \& Parry, 2018).

Tržište rada je i dalje mesto vidne nejednakosti između žena i muškaraca. U 2020. godini muškarci su u poređenju sa ženama imali veću verovatnoću da participiraju u globalnoj radnoj snazi (74\% : 47\%). Najuočljiviji rodni jaz i varijacije u pristupu žena tržištu rada u 2019. godini zabeležen je u Južnoj Aziji, Severnoj Africi i Zapadnoj Aziji, gde stopa učešća ženske radne snage nije prelazila $30 \%$ (UN DESA, 2020).

U okvirima afirmativnog regrutovanja i selekcije, u fokusu pažnje organizacija trebalo bi da budu nezaposleni samohrani roditelji, uvažavajući objektivne teškoće u vezi sa harmonizacijom obaveza na radnom mestu i privatnog života. Stoga je opravdana preporuka da organizacije krenu u susret ovakvim problemima i kreiraju planove za privlačenje i afirmativnu selekciju žena i drugih teže zapošljivih kategorija, koji mogu na jednom mestu da integrišu procenu personalnih politika, unapređenje fleksibilnih radnih mogućnosti, prilagođavanje postojećih radnih mesta i ponudu inoviranih planova za beneficije (Dessler, 2007: 88). 


\section{ZAKLJUČAK}

S obzirom da novinarska, ali i brojne druge profesije u medijskoj industriji, nemaju jasno precizirane minimalne kriterijume o tome ko sve može, sa kojim stepenom i vrstom školske spreme da se bavi složenim i odgovornim poslovima u tradicionalnim i digitalnim medijima, definisanje uslova prilikom selekcije kandidata prepušteno je poslodavcima, na osnovu analize i opisa poslova.

Minimiziranje rizika prilikom sprovođenja procesa regrutacije, a zatim i izbora kandidata na svim hijerarhijskim nivoima (pripravnici, administrativno-tehnički, profesionalno-stručni i menadžerski nivo), jedan je od najvažnijih zadataka u kontinuiranim naporima organizacije da obezbedi dovoljno kandidata, kao i da in dugoročno zadrži.

Pred menadžerima koji su zaduženi za realizaciju procesa zapošljavanja je sve veći izazov uvažavajući višegodišnji trend demografske erozije, kao i nedostatak vlastitog iskustva u zapošljavanju stranih državljanja, marginalizovanih grupa, starijih od 50 godina i penzionera.

\section{LITERATURA}

1. Agencija za privredne registre (2020). Registrovni mediji. Dostupno na: https://www.apr.gov.rs/инфографике.4318.html?infold=50 (22.08.2021).

2. Agencija za privredne registre (2021). Rodna struktura glavnih i odgovornih urednika i vlasnika izdavača medija. Dostupno na:

3. https://www.apr.gov.rs/\%D0\%B8\%D0\%BD\%D1\%84\%D0\%BE\%D0\%B3\%D1\%80\%D0 \%B0\%D1\%84\%D0\%B8\%D0\%BA\%D0\%B5.4318.html?infold=98 (10.12.2021).

4. Beardwell, J. and Wright, M. (2003). Recruitment and Selection. In: Beardwell, I., Holden, L. \& Claydon, T., Human Resource Management: A Contemporary Approach, London: Pearson.

5. Bogićević Milikić, B. (2006). Menadžment ljudskih resursa. Beograd, Ekonomski fakultet.

6. Bratton, J. \& Gold, J. (2003). Human Resource Management: Theory an Practice ( ${ }^{\text {rd }}$ ed.), London: Palgrave Macmillan.

7. Buble, M. (2006). Menadžment. Split: Ekonomski fakultet.

8. Budaković, A., Peštek, A. (2018) Upravljanje ljudskim resursima u kontekstu internog marketinga. Sarajevo: Ekonomski fakultet. 
9. CIPD. (2012). Flexible working provision and uptake: survey report. London: CIPD.

10. Cook, M. (2004). Personnel selection. Adding Value Through People, Chichester, West Sussex, England; Hoboken, NJ: J. Wiley.

11. Cooper, D., Robertson, I.T., \& Tinline, G. (2003). Recruitment and Selection: A Framework for Success, Cengage Learning EMEA (Australia) ( $1^{\text {st }}$ edition).

12. Čerović S. (2013). Upravljanje ljudskim resursima u hotelijerstvu. Beograd: Univerzitet Singidunum.

13. Čerović, S., Knežević, M. (2018). Menadžment u hotelijerstvu. Beograd: Univerzitet Singidunum.

14. Čerović S. (2019). Upravljanje ljudskim resursima u hotelijerstvu. Beograd: Univerzitet Singidunum.

15. Dessler, G. (2007). Osnovi menadžmenta ljudskih resursa. Beograd: Data status.

16. Đorđević Boljanović, J., Dražeta, L., Babić, L, Dobrijević, G. (2020). Razvoj karijere i poslovnih veština. Beograd: Univerzitet Singidunum.

17. Farashah, A. D., Thomas J., Blomquist T. (2019). Exploring the value of project management certification in selection and recruiting, International Journal of Project Management, 37, 14-26.

18. HRLAB. (2020). Najbolji procesi selekcije u Srbiji 2020. Subotica: Infostud. Dostupno na:https://www.hrlab.rs/hr-blog/novosti/oceni-put-do-posla-2020-kandidati-odlucili-da-su-poslodavci-sa-najboljim-procesom-selekcije-continental-subotica-logik-poslovni-softver-i-primus-group-hrm (10.11.2021).

19. Huffcutt, A., Conway, J., Roth, P., \& Stone, N. (2001). Identification and meta-analytic assessment of psychological constructs measured in employment interviews. Journal of Applies Psychology, 86(5), 897-913. https://doi.org/10.1037/0021-9010.86.5.897

20. Јовановић Божинов, М., Кулић, Ж., Цветковски, Т. (2008). Основи управљања људским ресурсима. Београд: Мегатренд универзитет.

21. Krstić, N. (2021). Obroj zaposlenih u medijskom sektoru beleži blagi skok u 2020. Beograd: Nezavisno udruženje novinara Srbije.

22. Lewis, C. (1985). Employee Selection. London: MacDonald \& Evans Hutchinson

23. Marchington, M. and Wilkinson, A. (2002). People Management and Development: Human Resource Management at Work. Chartered Institute of Personnel and Development, ( $2^{\text {nd }} \mathrm{Ed}$.)

24. Milić, Z. (2011). Menadžment ljudskih resursa. Beograd: Visoka strukovna škola za preduzetništvo.

25. Nikitović, V. (2019). U susret regionalnoj depopulaciji u Srbiji. Beograd: Institut društvenih nauka. 
26. Noe, A. R., Hollenbeck, J. R., Gerhart B., \& Wright, P. M. (2016). Human resource Management( $6^{\text {th }}$ ed.). New York: McGraw-Hill Education.

27. Pavlović, N. (2016). Poslovna kultura i etika. Vrnjačka Banja: Fakultet za hotelijerstvo i turizam.

28. Pržulj, Ž., Janković, M., Vemić Đurković, J. (2014). Put do najbolje odluke. Pale: DisCompny.

29. Ratković-Njegovan, B, Vukadinović, M. (2011). Sadržaj i efekti organizacione socijalizacije u poslovnim integracijama. Škola biznisa, 3.

30. Roberts, G. (2005). Recruitment and Selection ( $2^{\text {nd }}$ ed.). London: Chartered Institute of Personnel and Development.

31. Sindikat novinara Srbije SINOS (2020). Sindikalni objektiv - Povećan broj digitalnih medija, smanjena prava zaposlenih. Beograd. Dostupno na: http://www.sinos.rs/srpski/sindikalni-objektiv/12/2020/12/31/6352/ povecan-broj-digitalnih-medija-smanjena-prava-zaposlenih.html (20.11.2021).

32. Smeaton, D. \& Parry, J. (2018). Becoming an age-friendly employer: Evidence report. London: Center for Ageing Better.

33. Stoilkovska, A., Ilieva, J, \& Gjakovski, S. (2015). Equal employment opportunities in the recruitment and selection process of human resources. UTMS Journal of Economics, 6(2): 281-292. Skopje: University of Tourism and Management.

34. Stojadinović, Z., Marinković, D. (2015). Upravljanje ljudskim resursima u građevinarstvu. Beograd: Akademska misao.

35. Štangl Šušnjar, G., \& Zimanji, V. (2006). Menadžment ljudskih resursa. Subotica: Ekonomski fakultet.

36. Torrington, D., Hall, L., \& Taylor, S. (2004). Menadžment ljudskih resursa (5. izd.), Beograd: Data Status.

37. United Nations. (2005) - Population Challenges and Development Goals. New York. Available at: https://www.un.org/en/development/desa/population/publications/ pdf/ mdg/population-challenges.pdf (30.10.2021).

38. Vlada Republike Srbije. (2021). Strategija zapošljavanja u Republici Srbiji za period od 2021. do 2026. godine. Službeni glasnik RS, br. 16/21 I 36/21 - ispravka.

39. Vukonjanski, I., Šartije, T., Konstans, P., Hefer, H., Borojević, T., Radosavljević, K., Barber, Dž., Terijen, O., Rambo, T. (2012). Priručnik za upravljanje ljudskim resursima. Beograd: Kancelarija Saveta Evrope. 